\title{
IMPROVING STUDENTS' READING COMPREHENSION BY USING INQUIRY CHART STRATEGY TO THE NINTH GRADE STUDENTS OF SMP SWASTA KATOLIK BUDI MURNI 2 MEDAN
}

\author{
Rahul Sitinjak, Karisma E Tarigan, Anna Stasya Prima Sari \\ Catholic University of Saint Thomas \\ Email : karisma_tarigan@ust.ac.id
}

\begin{abstract}
The aim of this study is to find that Inquiry Chart Strategy works effectively on improving students' reading comprehension and to know the students' responses after being taught by using Inquiry Chart Strategy. In order to achieve the objectives of the study, a classroom action research was designed and carried out in this study. The participants of this study are 25 students of class IX-4 of SMP Swasta Budi Murni 2 Medan in the academic year 2018/2019. Test, observation sheet and field notes were used as the instruments for collecting data. The result of the study showed significant improvement of the students' skill in reading. It is proven by the students' mean score of each test: pre test is 50 with $12 \%$, formative test is 73,92 with $72 \%$, and post test is 87,6 with $92 \%$. And then the percentage of the students' improvement score from pre-test to post-test was $75.2 \%$. And the total percentage of strongly agree was $55.2 \%$. In addition, the analysis result of the observation sheet and field notes showed that Inquiry Chart Strategy changed the students' learning behaviour became better than before. They were more enthusiastic during the learning teaching process in each cycle. Based on the result of those study instruments, it can be concluded that using Inquiry Chart Strategy gives the improvement to the students' reading comprehension. This strategy is suggested to English teacher to apply it in teaching learning reading in order to improve students' reading comprehension. The writer also suggests to other writers to explore other studies on Inquiry Chart Strategy to improve the students' reading comprehens ion and try to apply this technique in different language skills.
\end{abstract}

Keywords: Reading Comprehension, Inquiry Chart Strategy, Classroom Action Research (CAR)

\section{INTRODUCTION}

Reading is one of four language skills that has important role for the students. One's academic success has a strong correlation with reading. Academically, reading is one of the most important skills. Reading can be defined as the ability to get understanding from written text. Second language reading can best be understood as a combination of skills and abilities that individuals bring to bear as they begin to read.

As we know teaching reading is not easy. Some students perceive that reading is boredom. The boredom can lead the students to have low motivation in doing the activity. Consequently, teachers should pay attention to how to make 
reading comprehension activities more amusing and enjoyable, so that the students feel more interested.

According to Brassell and Rasinski (2008:15) reading refers to the ability to comprehend or make meaning from written text. Furthermore, Klingner (2007:8) says that reading comprehension involves much more than readers' responses to text. Reading comprehension is a multi-component, highly complex process that involves many interactions between readers and writers. Reading comprehension is centered on the ability to derive meaning from the text. Without comprehension, students do not really comprehend the text. It is the teachers' responsibility to help the students to comprehend the text. Teachers need to assess students' reading needs. Furthermore, teachers should design and redesign courses in order to make an interesting learning process for students. From the definition, the writer concludes that reading comprehension is a process to read a text in order to get information from the text. It means that when we read, we have to understand the information or issue written in the text.

There are some texts that the ninth grade students of Junior High School learnt. They are descriptive text, narrative text, spoof text, report text, and explanation text. According to the English syllabus of the ninth grade of Junior High School in the second semester, the students are expected to be able to comprehend, descriptive text, narrative text and report text. Based on the writer's interview with Ms. Hutapea, S.Pd, the teacher of English at SMP Swasta Katolik Budi Murni 2 Medan, most of the students could not understand the content of the text after they had read it. As the result, the students not only find difficulties to get important information of the text but also answer the questions related to the text.

Based on the writer's observation towards the ninth grade students of SMP Swasta Katolik Budi Murni 2 Medan Class IX D in the Academic Year 2017/2018 when they were learning report text, it was found out that they were unable to comprehend the report text well. They tended to focus on the difficult words in the text rather than on the information from the text. Therefore, they read slowly word by word and had unreasonable expectation about how much they should be able to comprehend and to get information from the text. Besides, they have lack of English vocabularies. It makes them rely on their dictionaries in order to find out the meanings of the difficult words. In addition, not all of the students took part actively in learning teaching process. There were many passive students in the class when the teacher was teaching.

The problems above should be solved immediately. The teacher must consider a strategy that can help the students solve their problems to have good reading comprehension on report text. Regarding the situation, the writer chooses Inquiry chart strategy to solve the problems.

Inquiry chart (henceforth, I-chart) strategy is a strategy that enables students to gather information about a topic from several sources. Teacher design the I-chart around several questions about a topic. Students read or listen to several sources on 
the topic and record answers to the posed questions within the I-chart. The students generate a summary in the final row. Different answers from various perspectives can be explored as a class. Hoffman (in Antonacci 2011:121-122) states that I-chart strategy is data table that assists students in organizing information they retrieved from a wide range of material. I-chart is to help students learn to recognize that they need to read differently in different phases of the inquiry process. Students can set reading goals that can be tracked in the I-chart. This strategy works well in the classroom. It means that I-chart strategy is suitable to teaching reading comprehension and also enables students in making sense and develops their prior knowledge.

The writer is interested in applying I-chart strategy to improve students' reading comprehension because some research finding has shown good results of teaching English reading comprehension through I-chart strategy. The first research was carried out by Pariska (2012) entitled "The Effect of Using Inquiry chart (Ichart) Strategy toward Reading Comprehension in Report Text of the Second Year Students at MA. Daarun Nahdhah Thawalib Bangkinang”. It stated that the result of this research shows that I-chart strategy improved the students' reading comprehension. It is shown from the increase of mean scores of pre-test and posttests, compared to the mean score of pre-test which is 59,4 , the mean score of posttest increased up to 73,6 . Then, the mean score of post-test increased up to 78,1 . Based on the background of the study, the writer decides to conduct a research entitled Improving Students' Reading Comprehension by Using Inquiry Chart Strategy to the Seventh Grade Students of SMP Swasta Katolik Budi Murni 2 Medan.

\section{REVIEW OF LITERATURE}

\subsection{Reading}

Reading is approached as a thinking process which the students interact with the textual material and sort, evaluate, and react to its organization and content. Cain (2010:2) states, "Reading is an important skill, it is much more than a single skill: it involves the coordination of a range of abilities, strategies, and knowledge". The number and type of factors that are involved is reading, and the impact each has on the process, can be hard for skilled adult readers to appreciate, because reading is relatively effortless.

Reading is an ability that we can quite easily take for granted. Lucantoni (2005:29) says, "There must also be an interaction between the text and the receiver". Reading is form of communication between the reader and the writer. In the reading process, a reader must understand and catch the main idea of the text. At the same time, the writer tries to give understanding through the words. The readers must understand each sentence what they are saying. Reading is related to the cognitive process. In this process, the readers must be active to use their mind to understand what they are reading. They also try to solve the problem by their

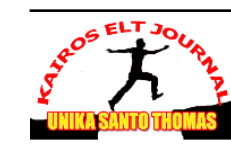


intelligence. Besides, reading is an active skill. In the reading process, a reader must be able to guess, predict, check, and ask oneself some questions related to the text.

Woods (2005:62) states that reading frequently seen as passive skill, in that it is receptive skill rather than productive skill. Nevertheless, to have meaning for reading, readers need to be active in the learning process. They need to be able to relate to and to understand the text, and this is an interactive process, because reading needs an interactive process.

The reader and the writer are the subject in the reading process. There is connection between them. A writer tries to explain his/her idea and the reader tries to understand the text he/she reads. Many reading specialists define that the essence of reading is and transaction and communication between the words of the writer and the mind of the reader. From the fact above, the writer can conclude that reading is a mental process to read a text to get information from the text. It means that when we read, we have to understand the information or issue that is explained on the text.

\subsubsection{The Process of Reading}

The process of reading refers to the person goes through to learn how to read. Nunan (2003:70) divides the models of reading processes into three categories: Bottom-up Models, Top-Down Models, and Interactive Models.

\section{Bottom-up Model}

The bottom-up model typically consists of lower-level reading process. Students start with the fundamental basics of letter and sound recognition, which in turn allows for morphemes recognition in what class followed by word recognition, building up to the identification of grammatical features, sentences, and longer texts. Letters, letter clusters, words, phrases, sentences, longer text, and finally meaning is order in achieving comprehension.

\section{Top-Down Model}

The top-down model on other hand begins with the idea that comprehension resides in the reader. The reader uses background knowledge, makes prediction, and searches the text to confirm or reject the predictions that are made. A passage can thus be understood even if all the individual words are not understood. Within a top-down approach to reading the teacher should focus on meaning generating activities rather than on mastery of word recognition.

\section{Interactive Model}

This third type combines elements of both bottom-up and top-down models if a pattern is synthesized based on information provided simultaneously from several knowledge sources. Nunan (2003:70) stresses, the best second language readers are those who can efficiently integrate both bottom-up and top-down processes.

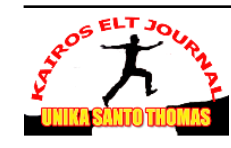




\subsubsection{The Purposes of Reading}

Students must have purposes when they are reading because students who are reading with a purpose cannot comprehend the text and know what they read better than those who have no purpose in reading. According to Grabe and Stoller (2002:13-15) the purposes of reading are classified into:

1. Reading to Learn from Text

Reading to learn typically occurs in academic and professional contexts in which a person needs to learn a considerable amount of information of a text. Reading to learn is usually carried out at a reading rate somewhat slower than general reading comprehension (primarily due to rereading and reflection) strategies to help remember information.

2. Reading to Search for Simple Information and Reading to Skim

Reading to search for simple information is a common reading ability though some researchers see it as a relatively independent cognitive process. It is used so often in reading tasks that it is probably best seen as a type of reading ability. Similarly, reading to skim to is a common part of many reading task and a useful skill in its own right. It involves, in essence a combination of strategies for guessing where important information might be in the text, and then using basic reading comprehension skills on those segments of the text until a general idea is formed.

3. Reading for General Comprehension

Reading for general comprehension is the most basic purpose for general. Underlying and supporting most other purposes for reading. General reading comprehension is actually more complex than commonly assumed. Reading for general information requires very rapid automatic processing of word, strong skills in forming a general meaning representation of main ideas and efficient coordination of many processes under very limited time constraints.

4. Reading to Integrate Information, Write and Critique Text

Reading to integrate information requires additional decisions about the relative importance of complementary, mutually supporting or conflicting information and the likely restricting of a rhetorical frame to accommodate information from multiple sources. Both reading to write and reading to critique text require abilities to compose, select and critique information from a text.

\subsection{Reading Comprehension}

The main purpose of reading is comprehension. Reading comprehension is an attempt to understand, evaluate, and recognize the author's idea of reading text. A reader needs comprehension to catch the content of message or information from the text. Snow (2002:11) states, "Reading comprehension is defined as the process of simultaneously extracting and constructing meaning through interaction and involvement with written language". The processes of constructing meaning is the process in which the reader combines their prior knowledge with the additional 
information from a text, draws the meaning of words, and connect it to reach the clear understanding of the written text.

Martin (1991:7) states, "Reading comprehension requires motivation, mental framework for holding ideas, concentration and good study technique". It means that in order to be successful in reading comprehension, the reader needs to motivate him/herself to concentrate on reading, try to form the mental frameworks for holding ideas, and the reader must have a good technique in reading. The process of comprehending involves decoding the writer's words and then using background knowledge to construct an approximate understanding of the writer's message.

Multiple choice question, short answer question, cloze test, and summarizing are examples of tasks used to asses comprehension. Language conveys meaning and allows the sharing of information, ideas, and perspectives. When written message are successfully understood, reading can be a wonderfully inspiring, enjoyable and transforming experience. The reader may comprehend a text when they can recognize the words and sentences of the text and know what the meaning is (obtain literal meaning), associate meaning both denotative and connotative from personal experiences and prior knowledge with the printed text, recognize how to all these meanings and/or his perception of them fit together contextually, make value judgment about the reading experience. Reader must find the idea that influence of the quality of their reading comprehension. From the explanation above, it is concluded that in reading comprehension, a reader must have available ability in the process of taking meaning from the text.

\subsubsection{Levels of Comprehension}

Burns, Roe and Ross (1990:177) state that there are four levels of comprehension that must be achieved in reading comprehension. The four levels of reading comprehension are identified as follows:

1) Literal comprehension

The basis of literal comprehension is recognizing main ideas, details, causes and effect, and sequences. It is important since it is as prerequisite for higher-level understanding. It means that the literal comprehension question tests the readers' ability to think within the text and consider what has been literally and explicitly stated. There is no hidden meaning, so the reader can take what is presented at face level.

2) Interpretive comprehension

Interpretive comprehension consists of (1) inferring main ideas of passages in which the main ideas are not directly stated; (2) inferring cause-and-effect relationships when they are not directly stated; (3) inferring referents of pronouns; (4) inferring referents of adverbs; (5) inferring omitted words; and (6) drawing conclusion. It means that interpretive meaning often hidden throughout the text and requires the use of inference and understanding the relationship between events and characters or causes and consequences.

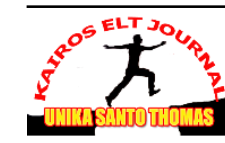




\section{3) Critical reading}

Critical reading is an activity in which the students are able to provide evaluation or take conclusion from a text accurately and compare the ideas in writing. A critical reader must be an active reader, who always asks, looks at the fact contained in the text to understand the meaning of the text itself.

4) Creative reading

Creative reading involves going beyond the material presented by the author. It requires readers to think as they read. It can also help students creatively explore their reading skills in which teacher should be able to be a model in teaching learning process.

\subsubsection{Teaching Reading Comprehension}

Brown (2000:7) states, "Teaching is an activity in which the teacher guides and facilitates learning, gives a chance for the learners to learn, and sets the condition for learning". Guidance is done by leading the students to do activities in the effort of getting knowledge. The teacher can help the students in gaining the knowledge by giving facilities such as tasks. By giving these tasks, the teacher lets the students study by themselves. To make the teaching and learning process run well, the teacher needs to set a good situation for the students to learn. In setting a good condition, the teacher must consider a classroom method or strategies that are used as this can influence the way he or she manages the class.

Based on definition above, teaching reading comprehension is a guidance that is done by the teacher to make learners reach their reading comprehension on the text using a certain strategy. Pang, et al. (2003:14) state "The teacher can lead the learners to understand a text by using some strategies on reading comprehension". The teacher's responsibilities in helping learners achieve these goals is to motivate them by selecting or creating appropriate texts, to design useful reading tasks, to set up effective classroom procedures, to encourage critical reading, and to create supportive environment for practicing reading.

\subsubsection{Principles for Teaching Reading Comprehension}

In the teaching of reading, the teacher cannot directly just teach reading to the students by giving texts and asks them to understand it. There are some principles which have to be considered by the teacher. As it is proposed by Harmer (2001:70-71), there are six principles in teaching reading as described as follows:

a. Reading is receptive; Reading is an incredibly active occupation. To do it successfully, we have to understand what the word means.

b. Students need to be engaged with what they are reading. As with everything else in lessons, students who are not engaged with the reading text, not actively interested in what they are doing.

c. Students should be encouraged to respond to the content of a reading text, not just to the language. It is important to study reading texts for the way they use

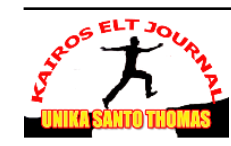


language, the number of paragraphs they contain and how many times they use relative clauses.

d. Prediction is a major factor in reading. When read the texts in our own langua ge, frequently have a good idea of the content before we actually read.

e. Match the task to the topic. Once a decision has been taken about what reading text the students are going to read, need to choose good reading task, the right kinds of questions, engaging and useful puzzle, etc.

f. Good teachers exploit reading texts to the full. They integrate the reading text into interesting class sequences, using the topic for discussion and further tasks, using the language for study and later activation.

From the explanation above the teacher must applied all of principles to teaching reading comprehension. They can help teacher make students more understand in learning reading comprehension.

\subsection{Report Text}

Report is a text which presents information about something, as it is. It is a result of systematic observation and analysis. Eudia \& Sudarmawati (2005:65-67) states that report text means a text which presents information about something to describe the way things are such as a man-made thing, animals, and plants.

In other words, report text describes the way of certain things and frequently refer to phenomenon of nature, animal, and scientific object. Mostly, report is written after getting careful observation.

The generic structure of report text:

a) General classfication: (introduce the topic of the report such as the class or subclass)

b) Identification: tells what the phenomenon under discussion is like in item of: part, qualities, behavior, habit, way or survival.

If the students are able to comprehend the indicators above, it means that the students know and understand about the report text. Indeed, the language feature of report are as follows:

1. The use of general nouns

2. The use of relating verbs

3. The use of behavioral verbs

4. The use of technical terms

5. Using simple present tense

In conclusion a report text is a text that is to show the information about something including general of thing and describe it. The information can be animals, plants, and humans.

\subsection{I-chart Strategy}

According to Hoffman (2000:143) I-chart is a data table that assists students in organizing information they retrieved from a wide range of materials. I-chart

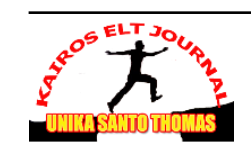


process offer another framework for teachers to support in the acquisition of knowledge through reading. The I-chart strategy is a strategy that enable students to gather information about a topic from several sources. Here, the students are required to explore the information from various sources and students record what they want to know about a topic and what they found from their reading. Thus, this strategy is a good way to develop the students' reading comprehension.

The I-chart procedure is organized into three phases including a Planning phase, Interacting phase, and Integrating/Evaluating phase. Each phase includes activities that will engage students in critically evaluating the topic.

According to Kuhlthau (2004:30) I-chart provides a way to visualize, organize, and synthesize ideas in the process that are particularly helpful in exploring, gathering, and creating phases. There are two important and challenging inquiry tasks for students, they are identify a substantive research question and then to construct an understanding of that question from the information and ideas they gather. Inquiry chart used at critical points in the inquiry process help students accomplish each of these tasks.

Students use a chart in the identify phase of inquiry to help them decide on the direction of their inquiry and to determine a focussed research question. Then again toward the end of the gather phase, they used charts to organize the information they have collected. In the create phase, charting helps students to make connection and synthesize their ideas to get ready to create away to share their learning. In guided Inquiry, students are given time to reflect on their I- chart as a learning tool so that they can make explicit connections to how this strategy could be applied to other life decissions that they might need to make.

According to Hoffman (2000:143) there are some processes in Inquiry chart, those are:

I. Planning phase:

In planning phase consist of 4 steps those are:

1. Topic identification

2. Question formation

3. I-chart construction

4. Materials collection

II. Interacting phase

In interacting phase consist of 4 steps those are:

1. Exploration of prior knowledge and beliefs

2. Sharing of interesting facts and new questions

3. Reading and rereading

III. Integrating phase

In integrating phase consist of 4 steps those are:

1. Summarizing

2. Comparing

3. Researching

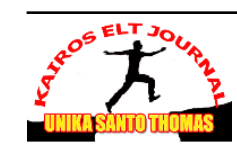




\section{Reporting}

The three phases above are the processes of I-chart strategy. In this process the teacher should be able to apply it and the to explain the material well. In addition, the three phase above is very good to help teacher explain materials.

\subsubsection{Teaching Reading by Using I-chart}

According to Hoffman (2000:143), teaching reading by I-chart strategy involves the following steps, those are: A topic for the Inquiry is selected, Key questions for the Inquiry are identified, Prior knowledge related to each question is shared and recorded, Data sources (e.g : textbooks, journals, trade-books) are gathered and read, Relevant information is recorded for the key questions, Summary answers for each question are constructed, Extended research is encouraged, and the last is Reports are presented.

According to Hoffman (2000:143) the steps of the I-chart strategy are: The teacher provides each student with a blank I-chart and assists with topic selection or provides the pre-selected topic, The students enggage in forming questions about the topic. Those question are placed at the top of each individual column, The rows are for recording any information students already know and the key ideas pulled from several different sources of information. The last row give students the opportunity to pull together the ideas into general summary, and Teachers may ask students to resolve completing ideas found in the seperate sources or develop new questions to explore based on any conflicting or incomplete information.

According to Hoffman (2000:143), the teaching reading by I-chart strategy is as follows: The teacher ask students to generate critical thinking question about a topic, The teacher distributes I-chart organizers, and has students record the questions in the appropriate spaces, Encourage students to think about discuss and record what they already know know about each questions, Allow time for independent research from multiple resources, Encourage students to reflect by nothing variations among sources, Ask students to develop a summary of their finding.

\subsubsection{The Purpose of the I-chart}

The main purpose of using I-chart strategy is to assist students in developing questions, accesing and organizing information for understanding, reporting and presenting research findings. And help the students to gather information they get from multiple sources and organize it for summarization, comparison and evaluation.

According to Hoffman (2000:143) there are some advantages of I-chart strategy, those are:

1. As students become more independent, they can develop individual I-chart that focus their Inquiry and organize their notes.

2. Students receive guided practice in synthesizing and summarizing information.

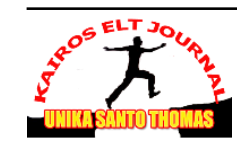


3. Students use multiple sources that provide a variety of information as a basis for an Inquiry project rather than answering identical questions based on single source.

4. This strategy fosters critical thinking and strengthens reading skills. I-chart can be used with the entire class, small groups, or individual work. Teachers can guide each student's chart development which allows for differentiated instruction as well as targeting the zone of proximal development. In addition, I-chart can serve as an evaluation tool for how much a student has learnt about a topic.

Based on the explanation above, it is clear enough that I-chart strategy is very useful for students to develop the reading skill but also it fosters students' thinking and students' perspective in their reading. I-chart strategy is suitable to improve students' reading comprehension.

\section{RESEARCH METHODOLOGY}

\subsection{The Research Design}

The research is conducted by applying Classroom Action Research (CAR), Burns (2010:10) says, "Classroom action research is a part of a broad movement that has been going on in education generally for some time. It is related to the ideas of reflective practice and the teacher as researcher. It means that Classroom Action Research is a process of research by the teacher for repairing and improving the learning in the classroom. Furthermore, McKay (2006:29) says, "Action research has three major characteristics: it is carried out by practitioners (i.e., classroom teachers), it is collaborative, and it is aimed at changing things. It means that action research can be done by a teacher in a classroom with the help of other teachers to discuss what and how to improve the classroom activities so that the students' achievement will be better,

Based on the definition above, the writer can conclude that classroom action research is form of research that applying an idea in a social or educational situation in order to improving or changing something to be better, or to get real effect on the situations. In doing this research, the writer will be helped by a collaborator to help defining and exploring certain problems and needs in the classroom. The writer acts as a real teacher who taught reading to the students by using I-chart strategy. The collaborator acts as an observer who observed the writer who applies I-chart strategy in improving students' reading comprehension.

\subsection{The Place and Time of the Study}

The study was conducted at SMP Swasta Katolik Budi Murni 2 Medan which is located on JL. Kapiten Purba. There are two reasons why the writer chooses the school as the location of the research. They are: 1) Based on primarily research that was done by the writer, it is needed to improve the reading

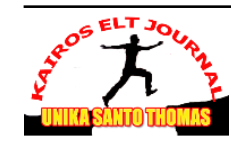


comprehension of the ninth grade students of SMP Swasta Katolik Budi Murni 2 Medan Class IX-D in the Academic Year of 2018/2019 through Inquiry chart strategy. 2) Based on the writer's knowledge there has never been any research about improving students' reading comprehension by using Inquiry chart strategy. This research was conducted in August 2018.

\subsection{The Subject of the Study}

The subject of the research is the seventh grade students of SMP Swasta Katolik Budi Murni 2 Medan Class IX D in the Academic Year of 2018/2019. The numbers of students in that class are 25 students, consisting of 15 female students and 10 male students.

\subsection{The Source of the Data}

Qualitative data are obtained from the observation teacher and students. Qualitative data consist of questionnaire, field notes and observation sheet. Quantitative data are obtained from the students' reading test before, during and after the learning teaching process.

In this data collection, the writer needs a collaborator. A collaborator in classroom action research is person who helps the writer to collect the data. The collaborator in this research is the teacher of English at the ninth grade students of SMP Swasta Katolik Budi Murni 2 Medan in the Academic Year of 2018/2019. She is Ms. Hutapea, S.Pd.

\subsection{The Instruments for Collecting Data}

Arikunto (2002:126) says, "There are many methods that can be used to collect data. They are test, observation, and questionnaire". In this study, the writer will use them to collect the data.

\subsubsection{Test}

Brown (2004:3) states, "Test is a method of measuring a person's ability, knowledge, or performance in a given domain". It is the series of question or exercise or another instrument used to measure the skill, knowledge, intellige nce, ability or the talent which possessed by individual or group. In this research the writer used two tests to measure students' reading comprehension namely pre-test and post-test. Pre-test is intended to assess the pre-existing reading comprehens ion of the subjects which is administered in the first meeting before the writer will conduct the research by applying Inquiry chart Strategy in the classroom while posttest is given to the students in the last meeting. Pre-test and post-test are in the form of multiple choice items consisting of 25 questions of pre-test and post-test. The questions which are constructed in the form of multiple choices consist of 25 items with options: A, B, C, D, and the score of each correct answer is four points. 


\subsubsection{Observation sheets}

Arikunto (2002:156) states, "Observation sheet is a convergence activity toward the object by using all the five sense. In the research, observation can be done through test, questionnaire, picture record, sound record, etc". The writer uses observation sheet to find out the progress of the implementation of Inquiry chart strategy. It is used to collect data on student activities, students' responses and it is a formal and informal observation of teaching while it is taking place in a classroom or learning environment. In this classroom observation the objects of observation are students and teachers' activities in English language teaching learning and result in Observation Sheet by using check list $(\sqrt{ })$.

The writer used two observation sheets, the first observation sheet is about the effectiveness of using I-chart Strategy and the second is about evaluation of all condition in learning teaching process. The observation sheet below is designed by adopting the descriptions of I-chart Strategy procedures by Hoffman (2000) with some modification is made for necessity of this research.

Table 1. Observation sheet 1

\begin{tabular}{|c|c|c|c|}
\hline $\begin{array}{l}\text { Inquiry Chart } \\
\text { Strategy }\end{array}$ & The Method's Contribution & $\begin{array}{l}\text { Progress } \\
\quad(\sqrt{ })\end{array}$ & Notes \\
\hline Planning Phase & $\begin{array}{l}\text { 1. A topic for I-chart is selected. } \\
\text { 2. Key questions for I-chart are } \\
\text { identified. } \\
\text { 3. Prior knowledge related to each } \\
\text { question is shared and recorded } \\
\text { 4. Data sources ( textbooks, internet, } \\
\text { television ) are gathered and read. } \\
\text { 5. Relevant information is recorded } \\
\text { for key questions } \\
\text { 6. Summary answers for each } \\
\text { question are constructed } \\
\text { 7. Make blank I-chart to evaluate the } \\
\text { students' abilities. } \\
\text { 8. Extended research is encouraged. } \\
\text { 9. Reports are presented. }\end{array}$ & & \\
\hline $\begin{array}{l}\text { Interacting } \\
\text { Phase }\end{array}$ & $\begin{array}{l}\text { 1. Introduce the strategy } \\
\text { 2. Sharing of Interesting. Facts and } \\
\text { new questions to make students } \\
\text { more understand. } \\
\text { 3. Reading the materials }\end{array}$ & & \\
\hline $\begin{array}{l}\text { Integrating } \\
\text { Phase }\end{array}$ & $\begin{array}{l}\text { 1. Summarizing all of about the } \\
\text { material. }\end{array}$ & & \\
\hline
\end{tabular}




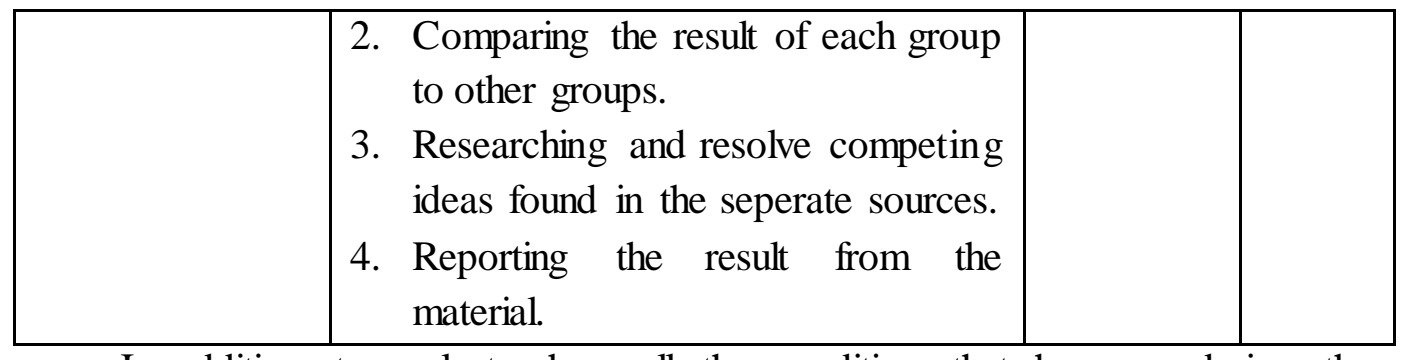

In addition to evaluate how all the condition that happens during the learning teaching process by using I-chart strategy to improve students' reading comprehension, the writer uses observation sheet 2. It can be seen in the table 3.2.

Table 2. Observation sheet 2

\begin{tabular}{|c|c|c|c|}
\hline & Description & Yes & No \\
\hline $\begin{array}{l}\mathrm{T} \\
\mathrm{E} \\
\mathrm{A} \\
\mathrm{C} \\
\mathrm{H} \\
\mathrm{E} \\
\mathrm{R}\end{array}$ & $\begin{array}{l}\text { 1. The teacher comes on the class on time. } \\
\text { 2. The teacher greets the students. } \\
\text { 3. The teacher does brainstorming to introduce the } \\
\text { topic. } \\
\text { 4. The teacher explains the material to the students. } \\
\text { 5. The teacher response the students question and } \\
\text { gives chance to all students to ask the topic. } \\
\text { 6. The teacher forms the students in several groups. } \\
\text { 7. The teacher asks the students to reading the topic. } \\
\text { 8. The teacher asks the students to identify the } \\
\text { information from the topic. } \\
\text { 9. The teacher asks the students to prepare the final } \\
\text { report and present the final report. } \\
\text { 10. The teacher prepares the blank I-chart to evaluate } \\
\text { the final report. } \\
\text { 11. The teacher makes evaluation from the final report } \\
\text { and concluded the lesson. } \\
\text { 12. The teacher manages the time effectively and } \\
\text { efficiently. }\end{array}$ & & \\
\hline $\begin{array}{l}S \\
T \\
U \\
D \\
E \\
N \\
T \\
S\end{array}$ & $\begin{array}{l}\text { 1. The students pay attention to the teacher's } \\
\text { explanation. } \\
\text { 2. The students ask the teacher if there is something } \\
\text { unclear. } \\
\text { 3. The students are divided into several group. } \\
\text { 4. The students reading the text. } \\
\text { 5. The students identified the information from the } \\
\text { text. } \\
\text { 6. The students prepare the final report and finally } \\
\text { present the final report. }\end{array}$ & & \\
\hline
\end{tabular}




\begin{tabular}{|c|l|l|l|l|}
\hline & $\begin{array}{l}\text { 7. The students feel interested in learning teaching } \\
\text { process. }\end{array}$ & & \\
\hline $\mathrm{S}$ & 8. The students do exercises seriously. & & \\
$\mathrm{I}$ & The classroom is comfortable (clean, calm, and & & \\
$\mathrm{T}$ & 2. The classroom is safe from crowded & & \\
$\mathrm{U}$ & 3. Teaching aids are available in the classroom & & \\
$\mathrm{A}$ & (whiteboard, marker, and book). & & \\
$\mathrm{T}$ & & & \\
$\mathrm{I}$ & & & \\
$\mathrm{O}$ & & & \\
$\mathrm{N}$ & & & \\
\hline
\end{tabular}

\subsubsection{Questionnaire}

Arikunto (2006:151) states, "A number of written question which used to get information from the respondent or the report about their selves, or the matter they known". The writer gave the questionnaire to the students. In constructing the questionnaires, the writer used checklist questionnaire. It means that the respondents answered the questions by giving check $(\sqrt{ })$ to the right column of the list. In this study, the writer used questionnaire to get additional information about the students' responses, the students' attitude, and the students' interest during learning teaching process through the application of I-chart Strategy.

Table 3. Questionnaire

\begin{tabular}{|c|c|c|c|c|c|c|}
\hline No & Deskripsi & $\begin{array}{l}\text { Sangat } \\
\text { Setuju } \\
(5)\end{array}$ & $\begin{array}{c}\text { Setuju } \\
\text { (4) }\end{array}$ & $\begin{array}{c}\text { Ragu- } \\
\text { ragu } \\
(3)\end{array}$ & $\begin{array}{l}\text { Tidak } \\
\text { Setuju } \\
\text { (2) }\end{array}$ & $\begin{array}{c}\text { Sangat } \\
\text { Tidak } \\
\text { Setuju } \\
\text { (1) }\end{array}$ \\
\hline 1 & $\begin{array}{l}\text { Saya tertarik dengan } \\
\text { Inquiry chart Strategy } \\
\text { yang digunakan dalam } \\
\text { proses belajar mengajar }\end{array}$ & & & & & \\
\hline 2 & $\begin{array}{l}\text { Saya mengerti materi } \\
\text { pembelajaran yang } \\
\text { diajarkan oleh guru } \\
\text { dengan menggunakan } \\
\text { Inquiry chart Strategy }\end{array}$ & & & & & \\
\hline 3 & $\begin{array}{l}\text { Saya termotivasi untuk } \\
\text { membaca menggunakan } \\
\text { Inquiry chart Strategy }\end{array}$ & & & & & \\
\hline
\end{tabular}




\begin{tabular}{|c|l|l|l|l|l|l|}
\hline 4 & $\begin{array}{l}\text { Saya memiliki kesempatan } \\
\text { untuk bertanya selama } \\
\text { proses belajar mengajar }\end{array}$ & & & & & \\
\hline 5 & $\begin{array}{l}\text { Inquiry chart Strategy } \\
\text { dapat meningkatkan } \\
\text { pemahaman membaca } \\
\text { khususnya pada teks } \\
\text { report. }\end{array}$ & & & & & \\
\hline
\end{tabular}

\subsubsection{Field notes}

Field note is a note, which is made to record the teaching learning process while the treatment is applied. Field notes used to collect the data activity during the teaching and learning process. The writer observes the activity of the students, whether they participate actively or not. Field notes used to help the writer to find out the progress of the students. In addition, the writer is able to see and take a note on the students' reading comprehension progress in classroom.

\subsection{The Procedures of Classroom Action Research}

The writer used Classroom Action Research (CAR) in conducting the research. The Classroom Action Research (CAR) model used by the writer is developed by Kemmis and McTaggart. This Classroom Action Research (CAR) is arranged into two cycles. They are cycle one and cycle two. Kemmis and McTaggart (2010:10) state that action research typically involves four broad phases in a cycle of research. The four phases in a cycle: (1) planning, (2) action, (3) observation, and (4) reflection. It can be seen in the figure 3.1

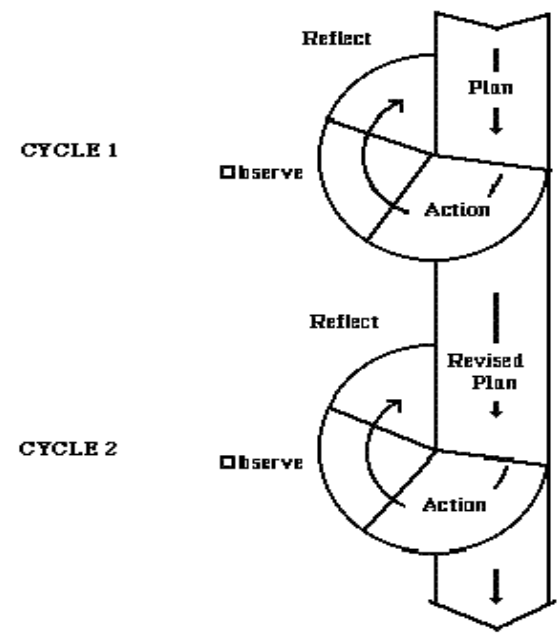

Figure 1. Burns' Classroom Action Research (CAR) Design

\subsubsection{Cycle 1}

Cycle 1 consists of four steps: planning, acting, observing, and reflecting. They are described as following. 


\section{1) Planning}

In the planning, the writer prepared to do the action. In the first step the writer prepared the teaching strategy and the procedure that was implemented in the research. The writer set the propose solution and the criteria of success, and then he prepares everything needed to conduct the research, such as the instructional materials, media, and the instruments used to collect and analyze the data. In this step the writer make a pretest. Based on the result of preliminary study, the researcher tries to improve students' reading skill through Inquiry chart strategy.

a. Providing the Strategy

The writer provides a strategy that is used to solve the students' problem by using I-chart strategy. The steps in providing this I-chart strategy will be explained as follows:

1. Select a topic studied in the curriculum and brainstorm with students about the POKKItopic. They might be wondering. As you solicit possible question to explore. Ask the students to choose three or four of the most interesting questions which will provide direction for students Inquiry.

2. Introduce the I-chart by modeling how to use this strategy to organize information on chart paper or the whiteboard. The writer provides the students with individual blank I-chart. And record questions in the boxes along the top.

3. Provide access to a variety of materials including websites and newspaper and magazines, and also article for students to consult to answer their target question.

4. Ask students to synthesize information from each question into a summary.

5. Students are now ready to write about their topic and they process to discuss each question and the information that relate to it.

b. Designing a lesson plan

A lesson plan was consisting of the objectives, the teaching method, the detailed teaching procedure and the assessment procedure is very important to prepare before the teacher enters the classroom. The lesson plan for this study was designed based on instructional objectives, materials and media, procedures of the implementation, and procedures of assessment.

\section{2) Action}

Teaching and learning reading activities will be applied through applying Inquiry chart strategy. Teacher divides students into seven heterogeneous team members. Then teacher will give the example of report text as a topic, and students have to identify the topic, and examine it carefully with their teams. Students will determine and discuss together about the characteristic and the feature of the object in the report text. They may find the other example in other sources for collecting information, such as from internet, another hand book, magazine, television, and

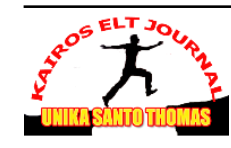


newspaper. After that, they have to present it in front of the class. Other teams should give the opinion or feedback to another team.

\section{3) Observation}

Observation is done at the same time with action. The writer observes the students' activities and takes note of the situation in class, including the students' activeness when the activity is in progress. The writer wills also notes problems arise during the Inquiry chart strategy is done. All the notes will be used as a consideration for the next cycle. The writer as a facilitator will also give helped if the students face problems during the activity. And while the learning process, collaborator observe by using check list $(\sqrt{ })$

\section{4) Reflection}

Reflection is the final phase. After observation the writer makes a reflection to know what happen during the research and evaluates the result of the action, so the writer makes the decision whether to stop the research or to continue with the next cycle. If the result of the first cycle is unsuccessful the research will be continued to the second cycle, with the same procedures and some adaptations.

\subsubsection{Cycle 2}

After conducting all the phases in cycle one, the writer conducted cycle two to make some better improvement of result. This cycle was focused on solving the problems that was found in cycle one. The second cycle also has four steps they are: planning, action, observing, and reflecting. The second cycle was revised from the first cycle.

\subsection{Techniques of Data Analysis}

The writer applied the following formula to calculate the students' score in order to measure the success of teaching learning process. The writer collected and analyze the quantitative data by computing their score of reading comprehension.

To know the mean of the students' score, the writer will apply the following formula which was formulized by Best \& Kahn (2002) as follows:

Where:

$$
\mathbf{M}=\frac{\sum \mathbf{x}}{\mathbf{N}}
$$

$\mathrm{M}=$ the mean of students' score

$\sum \mathrm{x}=$ the total score

$\mathrm{N}=$ the total number of students who do the test

To find the class percentage of students' score who pass the criterion minimum of completeness or Kriteria Kelulusan Mahasiswa (KKM), the writer applied the following formula which is also formulized by Best \& Khan (2002) as follows: 
Where:

$$
\mathbf{P}=\frac{\mathbf{R}}{\mathbf{T}} \mathbf{x} 100 \%
$$

$$
\mathrm{P}=\text { the percentage of students who get the point }
$$

$\mathrm{R}=$ the number of students who get point above $\geq 70$

$\mathrm{T}=$ the total number of students who take the test.

\section{DATA ANALYSIS AND DISCUSSION}

\subsection{The Data Analysis}

There are two types of data which were analyzed to find out the result of improving students' reading comprehension by using I-chart Strategy. They are quantitative and qualitative data.

\subsubsection{Quantitative Data}

The quantitative data was taken from the test result of students, namely pretest before treatment, formative test after cycle one, and post test after the end of cycle two. The complete result of the students' score in every test can be seen from the table and the histogram of score interval and the frequency.

Table 4. Pre-test Score Interval

\begin{tabular}{|c|c|c|}
\hline Score Interval & Frequency & Percentage \\
\hline $36-42$ & 10 & $40 \%$ \\
\hline $43-49$ & 4 & $16 \%$ \\
\hline $50-56$ & 5 & $20 \%$ \\
\hline $57-63$ & 0 & $0 \%$ \\
\hline $64-70$ & 3 & $12 \%$ \\
\hline $71-77$ & 3 & $12 \%$ \\
\hline $78-84$ & 0 & $0 \%$ \\
\hline $85-91$ & 0 & $0 \%$ \\
\hline $92-98$ & 0 & $0 \%$ \\
\hline $99-100$ & 0 & $0 \%$ \\
\hline Total & $\mathbf{2 5}$ & $\mathbf{1 0 0 \%}$ \\
\hline
\end{tabular}

Scoring interval is found by applying this following formula:

Scoring Interval $(\mathrm{P})=\frac{R}{K}=\frac{X_{n}-\mathrm{X}_{1}}{1+3,3 \log n}$

Where :

a) The division of distance $(\mathrm{R})=\mathrm{X}_{\mathrm{n}}$ (the highest score) $-\mathrm{X}_{1}$ (the lowest score). In which, $X_{n}=76$ and $X_{1}=36$ 
b) The sum of whole data $(K)=1+3,3 \log n$

c) $\mathrm{n}=$ the number of data, $\log _{25}=1,39$

Thus, $\mathrm{P}=\frac{76-36}{1+3,3 \log n}=\frac{40}{1+3,3 \times 1,39}=\frac{40}{1+4,58}=\frac{40}{5,58}=7,1=7$

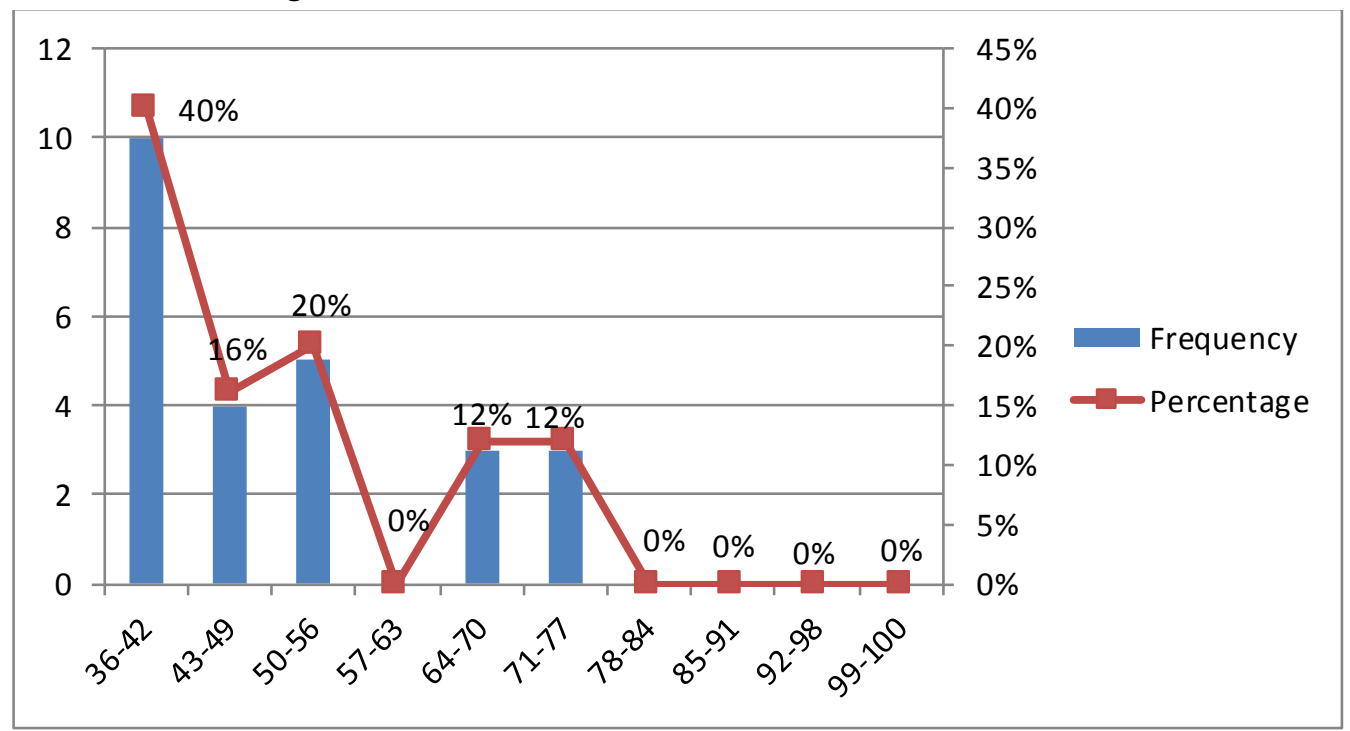

Chart 1. The Histogram of Pre-test Score

Based on the histogram of pre-test it could be seen that the dominant score interval was in 36-42, there are $10(40 \%)$ students. There are $4(16 \%)$ students who got pre-test score in interval 43-49, and $5(20 \%)$ students in interval 50-56. In addition, there are $3(12 \%)$ students who got score in interval 64-70, 3 (12\%) students who got score in interval 71-77. And the lowest of frequency for score interval 64-70, 78-84, 85-91, 92-98 and 99-100 are zero.

Table 5. Formative test Score Interval

\begin{tabular}{|c|c|c|}
\hline Score Interval & Frequency & Percentage \\
\hline $64-68$ & 7 & $28 \%$ \\
\hline $69-73$ & 3 & $12 \%$ \\
\hline $74-78$ & 10 & $52 \%$ \\
\hline $79-83$ & 3 & $4 \%$ \\
\hline $84-88$ & 1 & $4 \%$ \\
\hline $89-93$ & 1 & $0 \%$ \\
\hline $94-98$ & 0 & $0 \%$ \\
\hline $99-100$ & 0 & $0 \%$ \\
\hline Total & $\mathbf{2 5}$ & $\mathbf{1 0 0 \%}$ \\
\hline
\end{tabular}

Scoring Interval is found by appying this following formula:

Scoring Interval $(\mathrm{P})=\frac{R}{K}=\frac{X_{n}-\mathrm{X}_{1}}{1+3,3 \log n}$

Where: 
a) The division of distance $(\mathrm{R})=\mathrm{X}_{\mathrm{n}}$ (the highest score) $-\mathrm{X}_{1}$ (the lowest score). In which, $X_{n}=92$ and $X_{1}=64$

b) The sum of whole data $(K)=1+3,3 \log n$

c) $\mathrm{n}=$ the number of data, $\log _{25}=1,39$

Thus, $\mathrm{P}=\frac{92-64}{1+3,3 \log n}=\frac{28}{1+3,3 \times 1,39}=\frac{28}{1+4,58}=\frac{28}{5,58}=5,1=5$

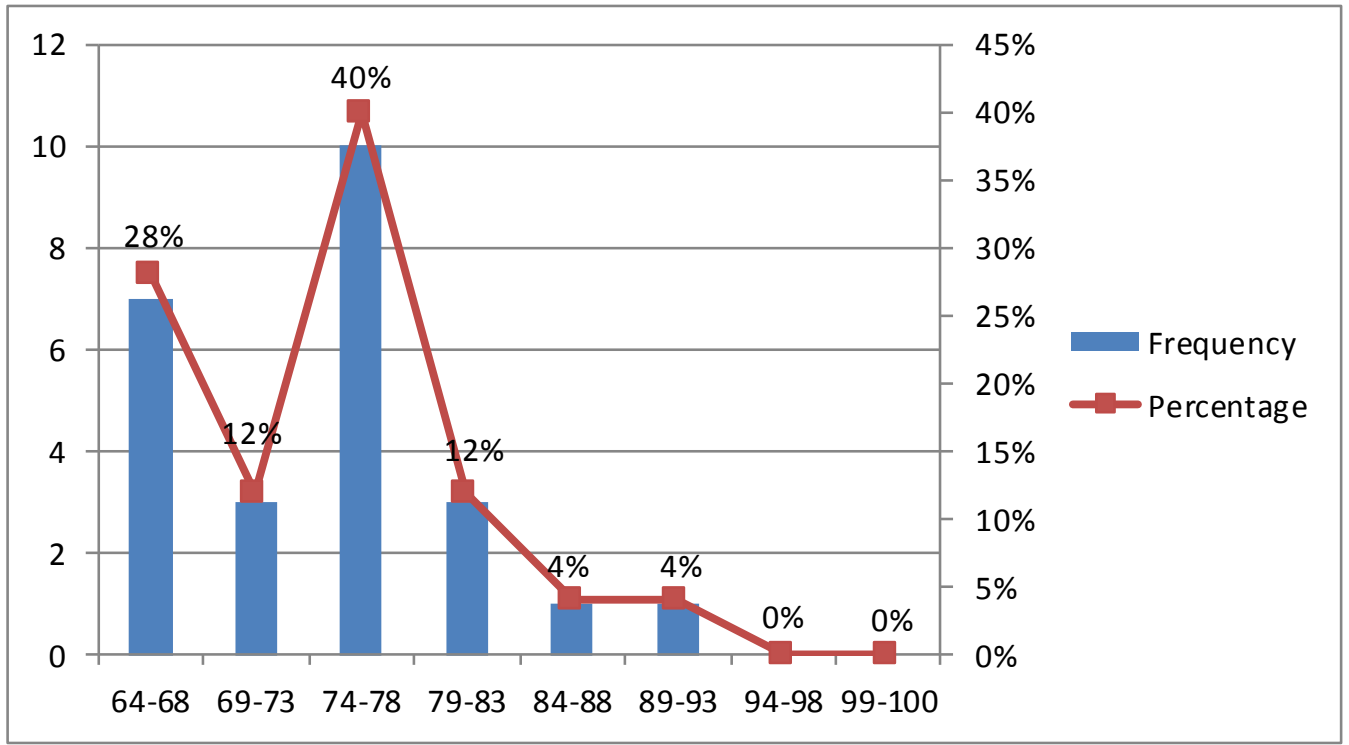

Chart 2. The Histogram of Formative Test Score

From the histogram of formative-test above, the dominant score interval was in 74-78, there are $10(40 \%)$ students. There are $7(28 \%)$ students who got score in interval 64-68, and $3(12 \%)$ students in interval 69-73. In addition, there are $3(12 \%)$ students who got score in interval 79-83, and there is $1(4 \%)$ student in interval 8488 and 89-93. And the lowest of frequency for score interval 94-98 and 99-100 are zero.

Table 6. Post-test Score Interval

\begin{tabular}{|c|c|c|}
\hline Score Interval & Frequency & Percentage \\
\hline $69-73$ & 2 & $8 \%$ \\
\hline $74-78$ & 1 & $4 \%$ \\
\hline $79-83$ & 7 & $28 \%$ \\
\hline $84-88$ & 2 & $8 \%$ \\
\hline $89-93$ & 1 & $4 \%$ \\
\hline $94-98$ & 12 & $48 \%$ \\
\hline $99-100$ & 0 & $0 \%$ \\
\hline Total & $\mathbf{2 5}$ & $\mathbf{1 0 0 \%}$ \\
\hline
\end{tabular}

Scoring Interval is found by applying this following formula:

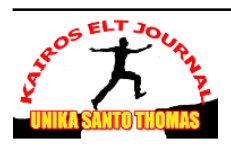


Scoring Interval $(\mathrm{P})=\frac{R}{K}=\frac{X_{n}-\mathrm{X}_{1}}{1+3,3 \log n}$

Where:

a) The division of distance $(R)=X_{n}$ (the highest score) $-X_{1}$ (the lowest score). In which, $X_{n}=96$ and $X_{1}=69$

b) The sum of whole data $(K)=1+3,3 \log n$

c) $\mathrm{n}=$ the number of data, $\log _{25}=1,39$

d) Thus, $\mathrm{P}=\frac{96-69}{1+3,3 \log n}=\frac{27}{1+3,3 \times 1,39}=\frac{27}{1+4,58}=\frac{27}{5,58}=4,8=5$

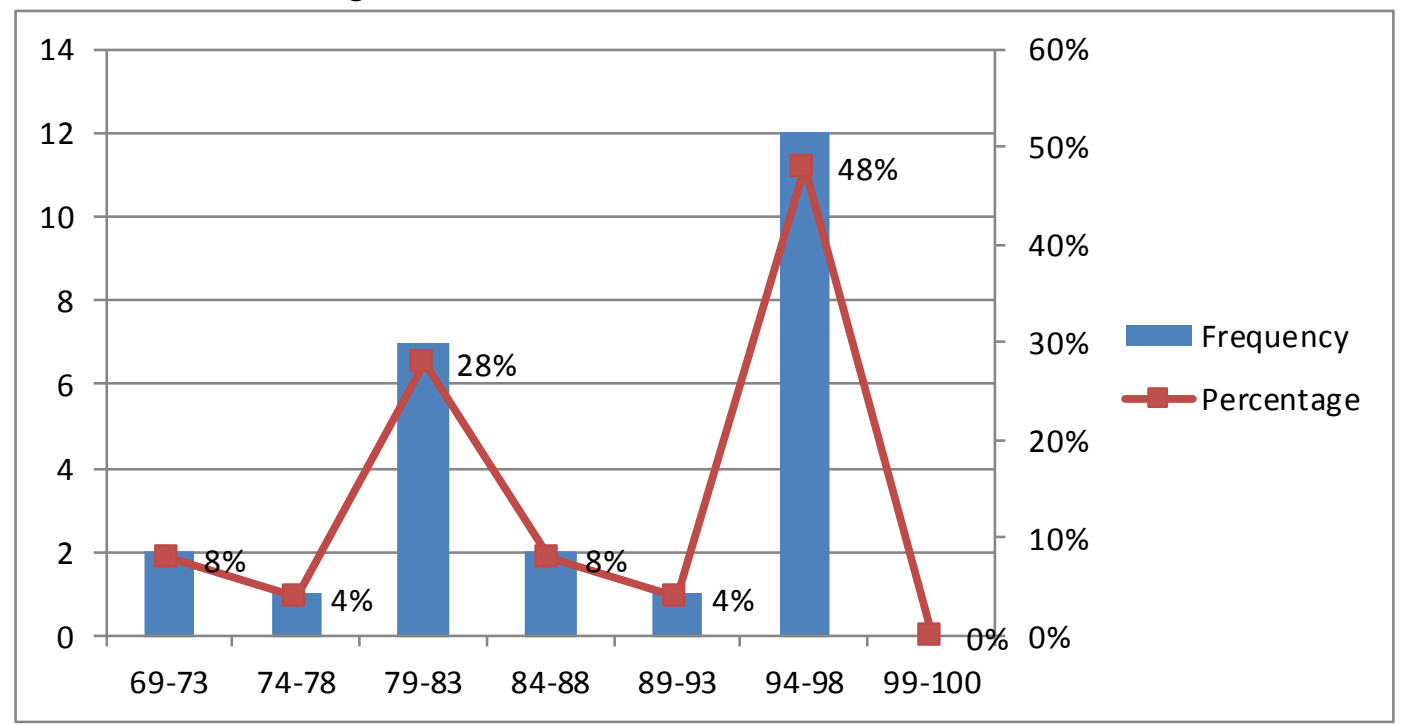

Chart 3. The Histogram of Post-test Score

From the post-test histogram above it could be seen that the dominant score of the interval was in 94-98, $(48 \%)$. It means that 12 students got post-test score in interval 94-98. The lowest of frequency for score interval 99-100 is zero. There are $2(8 \%)$ students who got post-test score in interval 69-73. In addition, there is 1 (4\%) student who got score in interval 74-78. There are 7 (28\%) students who got score in interval 79-83, and there are $2(8 \%)$ students who got score in interval 84 88 , and $1(4 \%)$ student who got score in interval 89-93.

Table 7. Quantitative Data

\begin{tabular}{|c|c|c|c|}
\hline Component & Pre-Test & Formative Test & Post-Test \\
\hline Mean & 50 & 73,92 & 87,6 \\
\hline Median & 50 & 76 & 94 \\
\hline Mode & 36 & 76 & 96 \\
\hline
\end{tabular}

To find out students' mean score in each test, the writer applied the following formula:

$$
\bar{X}=\frac{\sum X}{N}
$$


From the formula above, the result of the students' mean score could be seen as follows:

a) In the pre-test, the total score of the students is $\frac{1250}{25}=50$

b) In the formative test, the total score of the students is $\frac{1848}{25}=73,92$

c) In the post-test, the total score of the students is $\frac{2190}{25}=87,6$

To find out the percentage of the students' improvement score, the writer applied the following formula:

$$
\mathrm{P}=\frac{y^{1}-y}{y} \times 100 \%
$$

Where:

$$
\begin{aligned}
& \mathrm{P}: \text { percentage of students' improvement } \\
& \mathrm{y}^{1}: \text { post-test result } \\
& \mathrm{y}: \text { pre-test result }
\end{aligned}
$$

The percentage of the students' improvement score from pre-test to post-test is:

$$
\begin{aligned}
& \mathrm{P}=\frac{y^{1}-y}{y} X 100 \% \\
& \mathrm{P}=\frac{87,6-50}{50} X 100 \% \\
& \mathrm{P}=\frac{37,6}{50} X 100 \% \\
& \mathrm{P}=75,2
\end{aligned}
$$

Thus, the percentage of the students' improvement score from the pre-test to post-test is $75,2 \%$. The calculation of percentage of the students' improvement score was attached in Appendix 6. From the table of quantitative data, the writer presented the data of quantitative data in histogram.

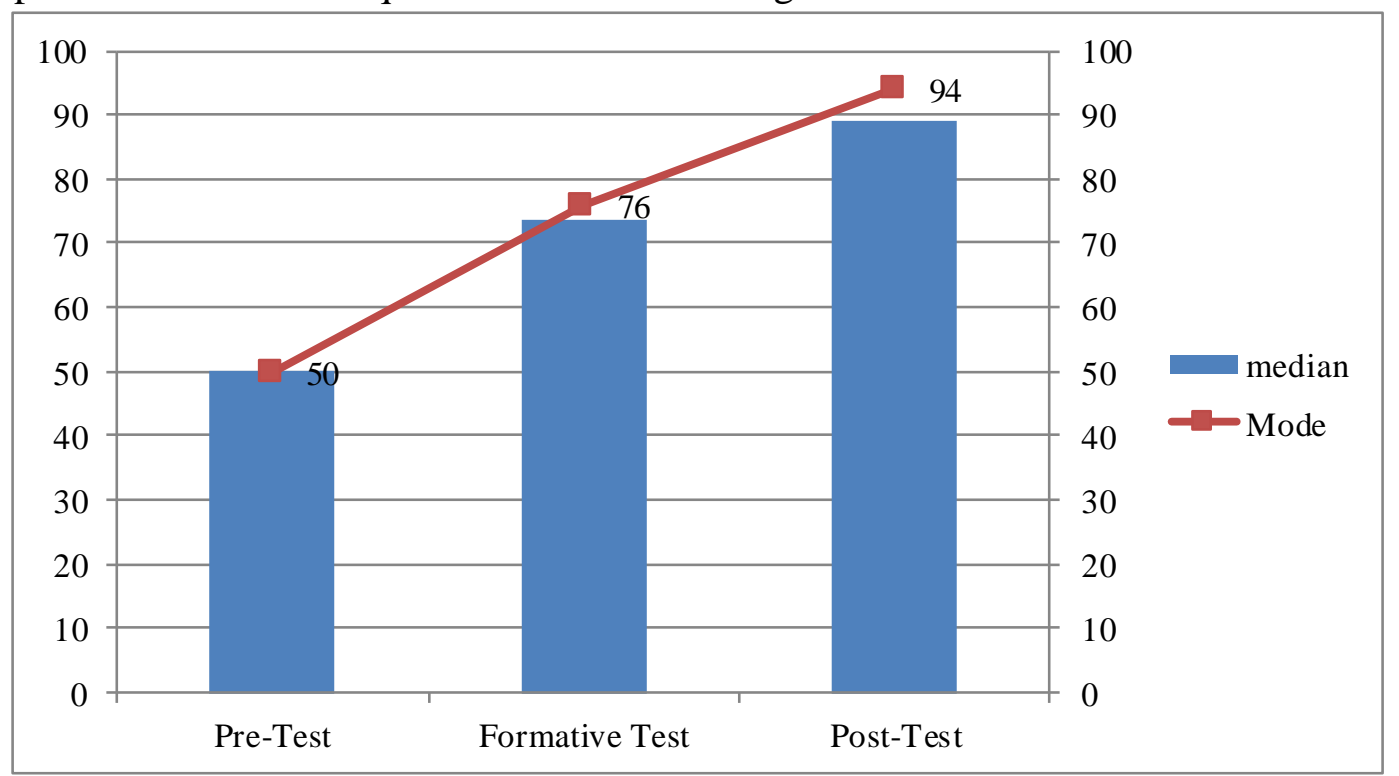

Chart 4. The Histogram of Quantitative Data

From the histogram result of quantitative data, it can be concluded that the students' mean score increased. The data showed that in pre-test, the students' mean 
score is 50 while the students' mean score in the formative test is 73,92 and in posttest is 87,6 . Then the mode and median of the students' score in post-test are higher than formative test. It means that there is improvement of the students' reading comprehension by using I-chart Strategy.

In this study if $70 \%$ students got $>70$ on their test, it means that Inquiry Chart Strategy was effective to improve students' reading comprehension. The percentage of the students' achievement in reading comprehension was presented as follows:

Table 8. Percentage of Students Achievement who Got Score $>70$

\begin{tabular}{|c|c|c|}
\hline Test & Students who got score $>\mathbf{7 0}$ & Percentage \\
\hline Pre-test & 3 & $12 \%$ \\
\hline Formative test & 18 & $72 \%$ \\
\hline Post test & 23 & $92 \%$ \\
\hline
\end{tabular}

To categorize the students who got score $>70$ or pass the Minimum Mastery Criterion/Kriteria Ketuntasan Minimal (KKM)) in the pre-test, formative test and post-test the following formula is applied:

$$
\mathrm{P}=\frac{R}{N} \times 100 \%
$$

a) In the pre-test the total number of the students who got $>70$

is $\frac{3}{25} \times 100 \%=12 \%$

b) In the formative test the total number of the students who got $>70$ is

$\frac{18}{25} \times 100 \%=72 \%$

c) In the post-test the total number of the students who got $>70$

is $\frac{23}{25} \times 100 \%=92 \%$

The whole percentage of the students' achievement in reading comprehension is presented in the following histogram.

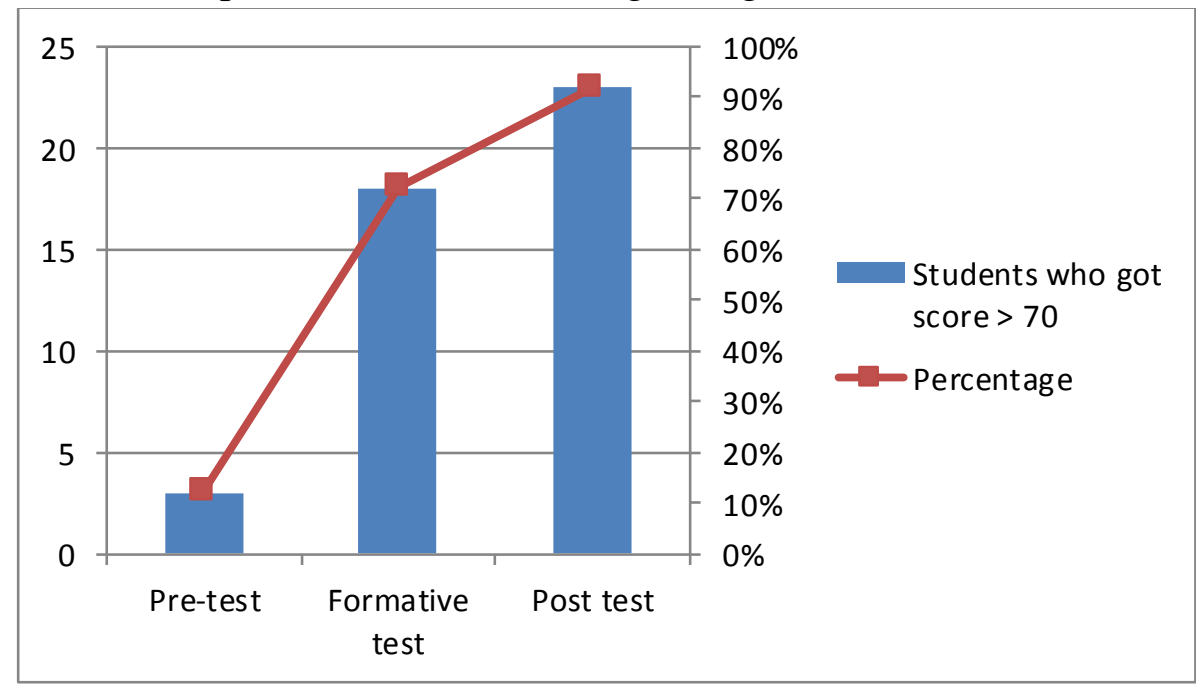

Chart 5. The Histogram of the Percentage of Students Achievement who got Score $>70$ 
In the pre-test, there are 3 students (12\%) who got score $>70$ and in the formative test there are 18 students $(72 \%)$ got score $>70$, whereas in the post-test there are 23 students (92\%) got score > 70. From the pre-test to post-test, there was significant development of the students' reading comprehension from $12 \%$ to $92 \%$. Thus the percentage improvement of students who got score $>70$ from the pre-test $(12 \%)$ to post-test $(92 \%)$ is $80 \%$. It can be concluded that I-chart strategy could help students in improving their reading comprehension.

\subsubsection{The Qualitative data}

The qualitative data were taken from field notes, observation sheets and questionnaire. The qualitative data are elaborated as follows:

\subsubsection{Field Notes}

Field notes are used to note all activities done by the writer and the students in the learning teaching process. The explanation was elaborated as follows:

\section{The First Meeting (Pre-test): Wednesday, August 01 ${ }^{\text {st }}, 2018$}

In the first meeting, the writer met the ninth grade students of SMP Swasta Budi Murni 2 Medan, and the writer was accompanied by Mrs. Hutapea the Englis h teacher at the school. The writer started the meeting by greeting and introducing himself to the students and explained the purpose of his coming to the school in order to conduct a research for accomplishing his Sarjana's thesis.

Before conducting the first cycle, the pre-test was given to measure how far the students' reading comprehension. In this occasion, the writer asked the students to answer the questions about report texts. The questions were in the form of multiple choice items consisting of 25 questions, with options A,B,C,D, and the score of each correct answer is four points. After finishing answering the test, the writer told the students that writer would meet the students in the next meeting.

From the result of pre-test, it was found that the students' reading comprehension is still low and only 4 students of 25 students could pass the Mastery Minimum Criteria (Kriteria Ketuntasan Minimal (KKM)). Thus, the writer decided to do the cycle I and cycle II in the next meeting, and there were eight meetings, 1 meeting for pre-test, 3 meetings for cycle I, 3 meeting for the cycle II and 1 meeting for post-test.

\section{Cycle I}

The following are the elaboration of the cycle I:

\section{The Second Meeting (Treatment I): Friday August 03 ${ }^{\text {rd }}, 2018$}

The second meeting was the beginning of cycle I. It started from 7.30 am until $08.50 \mathrm{am}$. The writer opened the class by greeting the students, asked the student to lead the prayer, and checked the attendance list of students. After that,

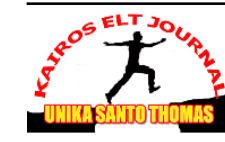


the writer prepared the teaching material before starting to teach report text, and also developed teaching process through the activity of students in the classroom. After that, the writer started to teach report text based on the problem faced by students toward reading skill in report text taken from the result of pre-test. They did not understand the language and the generic structure of report text which referred to some aspects of reading assessment. Therefore, the writer tried to solve the problem by using I-chart Strategy. In this meeting, the writer explained briefly about the concept and procedure of I-chart Strategy. But first, the writer was more focused on report text. The writer explained about definition, social function, generic structure, language features or other thing which was related to report text. Then, after the students got it, the writer gave a simple example of report text. Then, the writer and the students discussed it clearly.

\section{The Third Meeting: Wednesday, August $08^{\text {th }}, 2018$}

The third meeting was the second meeting of teaching and learning process in cycle I. It started from 08.50 am until $10.10 \mathrm{am}$. The writer continued the previous material about report text. Then, the writer reviewed it by asking students one by one to prove whether the students still remembered material about what the writer explained the last day. After finishing it, the writer continued to explain about the use of I-chart Strategy in learning reading. The writer explained them that in Ichart Strategy, students would be as writer or reviewer and then worked in group which consist of 5 members. On this occasion, the writer chooses the partners of each groups based on the score pre-test that they did yesterday. In this meeting, the writer asked them to choose one topic and get in from internet, book, or etc. And the writer gave a form of chart to each group and the students write the questions in the chart. After finishing all of question, one group presented their report text and other group gave a question about their topic.

\section{The Fourth Meeting (Treatment III): Friday, August $10^{\text {th }}, 2018$}

The fourth meeting was the third meeting of learning teaching process in cycle I and also the last stage in the classroom action research for cycle I. Thus the writer had to ensure the students understood by giving a test that was called formative test. Next, the writer told the students that they would be given a formative test. Before giving formative test, the writer gave brainstorming by asking the students some questions about the topic report text.

After finished answering the questions, the writer asked one students of each group to read and said their answer. Next, the writer gave the formative test to the students. The test is similar to pretest, in form of multiple choice items consisting of 25 questions from 5 passages with options: A,B,C,D, and the score of each correct answer was four points. After calculating the students' mean score in the formative test, it is concluded that the students' mean score is grow up, but still have to improve. Thus, the writer will conduct the cycle II.

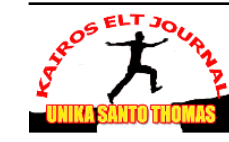




\section{The Fifth Meeting: Wednesday, August $15^{\text {th }}, 2018$}

In this meeting of the action in second cycle II, based on result of the formative test, the students' mean score is 73,92 and there are 14 students passed KKM. Thus the writer evaluate students' weakness in the previous meeting, the teacher helps the students that still difficult to comprehend the text. The writer reviewed the procedures of I-chart Strategy to the students. Next the writer asked the students choose the different topic and from different sources. After that, students discussed the topic and make questions and summary from their topic.

\section{The Sixth Meeting: Friday, August $\mathbf{2 4}^{\text {th }}, 2018$}

In this meeting, the writer continued the lesson. The writer asked each group to present their result of their discussion in the last meeting about the topic which they had chosen. And then they read their topic first, after that they continued read the questions they had make from their topic. And the other group make a question to that group. The writer saw that the students more active by using I-chart Strategy.

\section{The Seventh Meeting: Wednesday, 29 ${ }^{\text {th }}, 2018$}

The seventh meeting was the third meeting of teaching and learning process in cycle II. Teacher greeting the students, and checking the students' attendence list. In this meeting the material was still about I-chart Strategy. The writer taught them about the generic structure and some examples. After that, the writer gave 15 minutes to students to prepare other group which did not present their report text. After that, he called the group to the front of class to present their topic. The writer recorded the group which understanding about report text. Then, the writer asked about their difficulties in learning process by using I-chart Strategy. After that, the writer told them to prepare their self in the next coming Wednesday. The writer and the students pray together and said good bye.

\section{The Eighth Meeting: Wednesday, August $31^{\text {th }}, 2018$}

The meeting was the last meeting of the study. In the last meeting, the writer gave the post test to know the result of students' reading comprehension after conducting by using I-chart Strategy. Before giving the test the writer told to the students that they would be given a test. The questions were different from the test before, in the form multiple choice item consisting of 25 questions from 5 passages with option A,B,C,D and the score of each correct answer is four points. The students read the text seriously than before. Some of the students still asked about some difficult words to the writer. They are more confident in their reading and finished their work faster.

Finally, the writer ended the class by thanking and taking photos with them. He closed the meeting by saying prayed and saying good bye to the students.

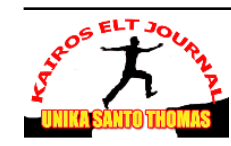




\subsubsection{Observation Sheets}

The writer used two observation sheets. The first observation sheet was used to observe the effectiveness of using I-chart Strategy, and the second observation sheet was used to observe all the condition learning teaching process.

The observation sheet I was filled by the collaborator. The collaborator observed the students during teaching learning process. The writer found in cycle I there was some students who were still confused about the concept of I-chart Strategy and some students did not understand what they read. But, in the observation sheet cycle II showed that the students progress in reading comprehension by using I-chart Strategy. The observation sheet 2 was filled by the collaborator. The collaborator observed the students during teaching learning process. The observation report based on the observation sheet in cycle I, namely, the writer could not open the class well, explain the material well and close the meeting well. Even though, there was some lack, namely; the writer could not manage the time well and also some of students did not pay attention to the writer.

But, the observation cycle II showed that the writer could do everything well, namely: opening the class well, explaining the material well, giving motivation, leaving the class on time, and also the students paid attention and give their participation during the learning teaching process. Thus, based on the result of observation, it was concluded that the students were more eager and interested in reading comprehension.

\subsubsection{Questionnaire}

This questionnaire was filled by the students. This questionnaire was given to students in order to find out the students' responses, the students' achievement, and the students' interest during teaching reading comprehension by using I-chart Strategy.

Based on the result of questionnaire, the writer presented it in the table.

Table 9. Questionnaire Result

The score of students' responses in the questionnaire was calculated as

\begin{tabular}{|c|c|c|c|c|c|c|c|}
\hline No & Description & \multicolumn{2}{c|}{$\begin{array}{c}\text { Strongly } \\
\text { Agree }\end{array}$} & \multicolumn{2}{c|}{ Agree } & \multicolumn{2}{c|}{$\begin{array}{c}\text { Quite } \\
\text { Agree }\end{array}$} \\
\cline { 3 - 8 } & $\begin{array}{c}\text { Sum of } \\
\text { Students }\end{array}$ & $\%$ & $\begin{array}{c}\text { Sum of } \\
\text { Students }\end{array}$ & $\%$ & $\begin{array}{c}\text { Sum of } \\
\text { Students }\end{array}$ & $\%$ \\
\hline 1 & Students' interest & 12 & $48 \%$ & 12 & $48 \%$ & 1 & $4 \%$ \\
\hline 2 & $\begin{array}{c}\text { Students' } \\
\text { understanding }\end{array}$ & 14 & $64 \%$ & 8 & $32 \%$ & 3 & $12 \%$ \\
\hline 3 & $\begin{array}{c}\text { Students' } \\
\text { motivation }\end{array}$ & 11 & $44 \%$ & 10 & $40 \%$ & 4 & $16 \%$ \\
\hline
\end{tabular}

follows:

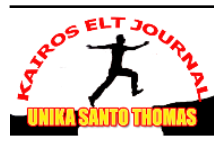


KAIROS ELT JOURNAL, Vol. 3 No. 3 Desember 2019

Copyright@2019, ISSN: 2580-4278

\begin{tabular}{|c|c|c|c|c|c|c|c|}
\hline 4 & $\begin{array}{c}\text { The Students' } \\
\text { Chance in asking }\end{array}$ & 15 & $60 \%$ & 7 & $28 \%$ & 3 & $12 \%$ \\
\hline 5 & $\begin{array}{c}\text { The Students' } \\
\text { Improving in } \\
\text { reading }\end{array}$ & 17 & $68 \%$ & 7 & $28 \%$ & 1 & $4 \%$ \\
\hline
\end{tabular}

Where:

$\mathrm{M}=$ the score in percentage of each scale value

$\sum x=$ the total score of Strongly Agree, Agree, Quite Agree, Disagree, Strongly

Disagree

$\mathrm{N}=$ the total of Strongly Agree, Agree, Quite Agree, Disagree, Strongly Disagree

1. Total percentage of Strongly Agree

$\mathrm{M}=\frac{\text { Total of Strongly Agree }}{\text { Total score of students' } \text { responses }} X 100 \%=\frac{69}{125} X 100 \%=55.2 \%$

2. Total percentage of Agree

$\mathrm{M}=\frac{\text { Total of Agree }}{\text { Total score of students' } \text { responses }} X 100 \%=\frac{44}{125} X 100 \%=35.2 \%$

3. Total percentage of Quite Agree

$\mathrm{M}=\frac{\text { Total of Quite Agree }}{\text { Total score of students' } \text { responses }} X 100 \%=\frac{12}{125} X 100 \%=9.6 \%$

From the of questionnaire result, the writer presented the data through histogram. The histogram was presented as follows:

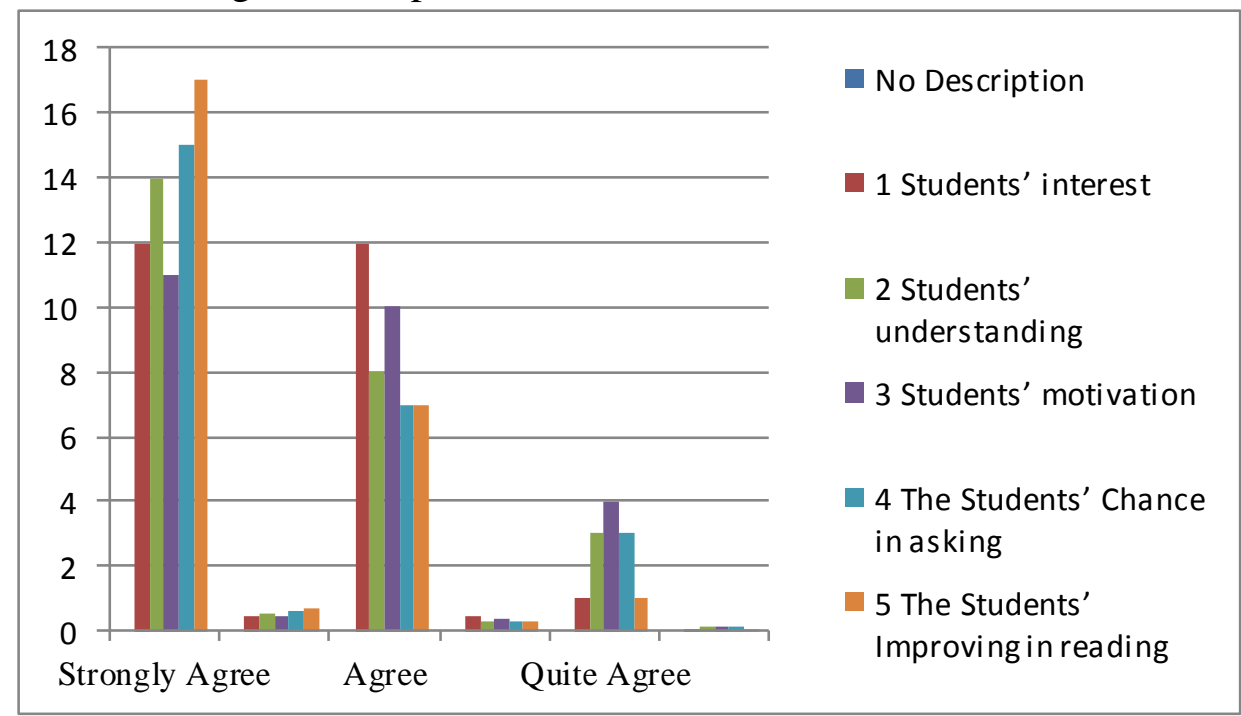

Chart 6. the Histogram of Questionnaire

Based on the histogram, the students' responses of Strongly Agree are $55.2 \%$, the students' responses of Agree are 35.2\% and the students' responses of Quite Agree are $9.6 \%$. Most of the students are Strongly Agree with I-chart Strategy. 
Based on the result of the questionnaire, it can be concluded that the students' responses towards learning teaching process of reading comprehension by using I-chart Strategy are good because the students strongly agree to learn reading comprehension by using I-chart Strategy.

\subsection{Discussion}

Inquiry Chart Strategy was applied to improved the students' reading comprehension of ninth grade students of SMP Swasta Budi Murni 2 Medan. As the collaborator, the English teacher and the writer collaboratively discussed the result of the study. They concluded that the use of I-chart Strategy could be the effective way to help students in reading. It was shown in histogram 4,4, in which the mean score of each test improved. The mean score of pre-test was 50, formative test was 73,92, and the post test was 87,6. And then the percentage of the students' improvement score from pre-test to post-test was $75.2 \%$. Those score showed that the second cycle was better than the first cycle. Besides that, the improvement can be seen from the observation sheet and field notes. The students' responses towards the learning teaching process of reading comprehension by using I-chart Strategy were strongly agree. It proved from the total percentage of strongly agree was $55.2 \%$. In addition most of the students were more active and enthusiastic during the process of teaching and learning that started from the first to the second cycle when the technique was applied.

Based on explanation above, I-chart Strategy was suitable strategy to improve students' reading comprehension because gave students a chance to more active in discussion with their group and more better. As the result, the students' reading score test improved in both of cycle after being taught with I-chart Strategy and also gave a good response and condition to all students in teaching learning process.

\section{CONCLUSION AND SUGGESTION}

\subsection{Conclusion}

After analyzing and discussing the data, the writer draws the following conclusion:

1. The application of I-chart Strategy can improve the students' reading comprehension. It was found out that the students' achievement of reading comprehension on report texts improved from pre-test to post-test after I-chart Strategy was applied. The increase in the students' total mean score in pre-test is 50 , the formative test is 73,92 , and post-test is 87,6 . Meanwhile, the students' score percentage who passed Mastery Minimum Criteria (Kriteria Kelulusan Minimum (KKM)) from pre-test is $12 \%$, the formative test is $72 \%$, and the posttest is $92 \%$, the students' score and percentage continuously increased in each test. And then the percentage of the students' improvement score from pre-test to post-test was $75.2 \%$. Therefore, it is concluded that the application of I-chart 
Strategy can improve the students' reading comprehension on report text successfully.

2. The students' responses were strongly agrees. It proved from the total percentage of strongly agree was $55.2 \%$. And then they felt enthusiastic and motivated after being taught with I-chart Strategy. It could be seen from the qualitative data such as observation and field notes during the study.

\subsection{Suggestions}

In this part, the writer would like to give some suggestions as follows:

1. The English teachers should use I-chart strategy in teaching students' reading comprehension. To use this strategy the teacher must creative and motivated students in learning English.

2. The students of SMP Swasta Katolik Budi Murni 2 Medan are suggested to be more active in the class and serious in learning English and also practice their English. It can improve their interest in learning English and also can improve their reading comprehension.

3. The result of this study is expected to be able to provide other writers valuable information about how to improve students' reading comprehension by using Ichart Strategy.

\section{BIBLIOGRAPHY}

Antonacci, P. A. 2011. Developing Content Area Literacy. London: SAGE Publications.

Arikunto, S. 2002. ProsedurPenelitianSuatuPendekatanPraktik (EdisiRevisi V). Jakarta: RinekaCipta.

2006. PenelitianTindakanKelas (Classroom Action Research). Jakarta: BumiAksara.

Best, J.K., \& Kahn, J.V. 2002.Research in Education (9 ${ }^{\text {th }}$ Edition). Reno: Allyn Bacon.

Brassell, D. \&Rasinski, T. 2008. Comprehension that Works. Huntington Beach: Shell Education.

Brown, H.D. 2000.Principles of Language Learning and Teaching. New York: Longman.

2001. Teaching by Principle: An Interactive Approach to Language Pedagogy. New York: Longman.

2004. Language Assessment: Principles and Classroom Practices. New York: Pearson Education.

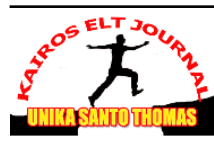


Burns, A. 2010.Doing Action Research in English Language Teaching: A Guide for Prationers. New York: Routledge.

Burns, P.C., Roe, B.D., \& Ross, E.P. 1990. Teaching Reading in Today's Elementary School. Boston: Houghton Mifflin Company.

Cain, K. 2010. Reading Development and Difficulties. West Sussex: British Psycological Society and Blackwell Publishing.

Eudia, G., \&Sudarmawati. 2005. Look Ahead (An English Course for Senior High School Students Year XI). Jakarta: Erlangga.

Grabe, W., \&Stoller, F. L. 2002.Teaching and Researching Finding. Edinburg: Pearson Education.

Harmer, J. 2001.How to Teach English. Cambridge: Longman.

Hoffman, J.V. 2000.Balancing Principles for Teaching Elementary Reading. London: Lawrence Erlbaum.

Kemmis, S., \&McTaggart, R. 2010. The Action Research Planner (3 ${ }^{\text {rd }}$ Edition). Geelong: Peakin University Press.

Klingner. 2007. Teaching Reading Comprehension to Students with Learning Difficulties. New York: The Gulidford Press.

Kuhlthau. 2004. Guided Inquiry Design. California: Martin Trails Publishing LLC.

Lucantoni, P. 2005. Teachingand Assessing Skills in English As A Foreign Language. Cambridge: Cambridge University Press.

Martin, D. 1991. How to be Successful Students. California: Martin Trails Publishing LLC.

Mckay, S.L. 2006. Researching Second Language Classrooms. London: Lawrence Erlbaum Associates.

Nunan, D. 2003. Practical English Language Teaching.Newyork: McGraw Hill.

Pang, S. et al. 2003. Teaching Reading. Brussels: International Academy of Education.

Pariska, D. 2012. The Effect of Using Inquiry Chart (I-chart) Strategy toward Reading Comprehension in Report Text of the Second Year Students at MA. Daarun Nahdhah Thawalib Bangkinang. An Unpulished Sarjana's Thesis, Faculty of Teachers Training and Education: State Islamic University of Sultan Syarif Kasim Riau. 
KAIROS ELT JOURNAL, Vol. 3 No. 3 Desember 2019

Copyright $\bigcirc 2019$, ISSN: 2580-4278

Snow, C. 2002. Reading for Understanding: Toward An R\&D Program in Reading Comprehension. Washington DC: Rand Cooperation.

Strong,W.R. 2002. Reading for Academic Success.Merlbourn: Gorwin Press.

Woods, C. 2005. Teaching and Assessing Skills in English As A Foreign Language. Cambridge: Cambridge University Press. 